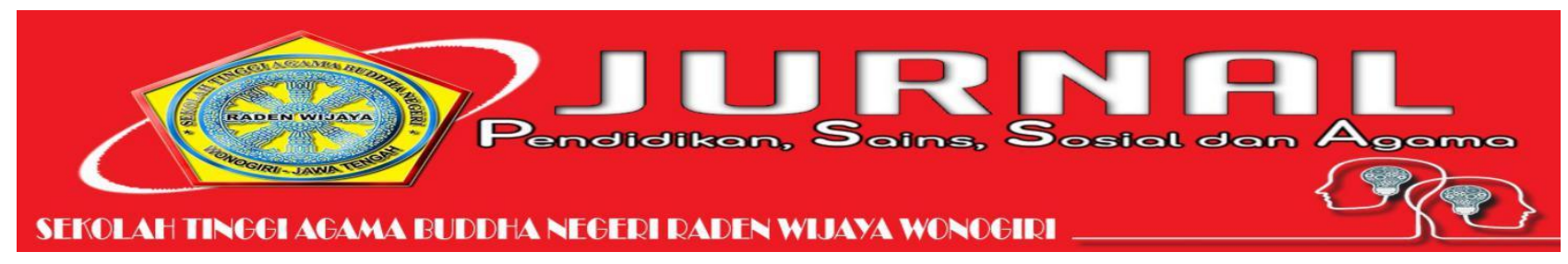

\title{
PENGGUNAAN INFORMASI AKUNTANSI PADA PELAKU UMKM
}

\author{
Nur Setya Handayani ${ }^{1}$, M. Elfan Kaukab ${ }^{2}$, Wiji Yuwono ${ }^{3}$ \\ Universitas Sains Al-Qur'an, Wonosobo, Indonesia \\ nursetyahandayani20@gmail.com, elfan@unsiq.ac.id, wiji.yuwono.psc20@mail.umy.ac.id
}

\begin{abstract}
Abstrak
Tujuan penelitian ini adalah untuk mengetahui faktor-faktor yang mempengaruhi penggunaan informasi akuntansi pada pelaku UMKM di KabupatenWonosobo. Variabel independen dalam penelitian ini adalah pengetahuan akuntansi, pengalaman usaha, motivasi kerja, jenjang pendidikan dan skala usaha. Sedangkan variabel dependennya adalah penggunaan informasi akuntansi. Metode pengumpulan data dalam penelitian ini menggunakan simple random sampling, diperoleh sampel 100. Metode pengumpulan data dalam penelitian ini menggunakan kuesioner. Penelitian ini menggunakan teknik analisis data statistik regresi dengan bantuan SPSS. Hasil penelitian ini menunjukkan pengetahuan akuntansi, pengalaman usaha, motivasi kerja, jenjang pendidikan, dan skala usaha berpengaruh positif terhadap penggunaan informasi akuntansi. Keterbatasan dalam penelitian ini adalah koefisien determinasi sebesar 54,1\%. Artinya, masih terdapat variabel bebas lainya yang bisa mempengaruhi penggunaan informasi akuntansi yang tidak diteliti dalam penelitian ini. Agenda penelitian yang akan datang disarankan memperluas periode pengamatan yang lebih lama untuk mendapatkan hasil yang lebih baik dan menambah variabel penelitian yang berpengaruh terhadap penggunaan informasi akuntansi.
\end{abstract}

Kata Kunci: pengetahuan akuntansi, pengalaman usaha, motivasi kerja, jenjang pendidikan, skala usaha, penggunaan informasi akuntansi

The purpose of this study was to determine the factors that influence the use of accounting information on MSME actors in Wonosobo Regency. The independent variables in this study are accounting knowledge, business experience, work motivation, education level, and business scale. While the dependent variable is the use of accounting information. The method of collecting data in this study using simple random sampling obtained a sample of 100. The method of data collection in this study using a questionnaire. This study uses statistical regression data analysis techniques with the help of SPSS. The results of this study indicate that accounting knowledge, business experience, work motivation, education level, and business scale have a positive effect on the use of accounting information. The limitation of this study is the determination coefficient of 5,4\%. This means that other independent variables can affect the use of accounting information that was not examined in this study. The future research agenda is suggested to expand the longer observation period to get better results and add research variables that affect the use of accounting information.

Key Word: accounting knowledge, business experience, work motivation, education level, business scale, use of accounting information 


\section{PENDAHULUAN}

Usaha Mikro, Kecil dan Menengah yang biasa disebut UMKM merupakan bentuk unit usaha yang dikelola oleh perorangan maupun kelompok dalam masyarakat. Keberadaan UMKM memang tidak bisa dipungkiri menjadi salah satu tulang punggung perekonomian Indonesia. Sektor UMKM secara umum berperan dalam menciptakan lapangan kerja, mendorong pertumbuhan ekonomi dan mempercepat pemerataan pendapatan melalui kesempatanberusaha (Kaukab, 2000)

Berdasarkan data dari Kementerian Koperasi dan UMKM tahun 2013, UMKM di Indonesia mengalami pertumbuhan 7\%-8\% setiap tahun. Sebanyak 56,5 juta jumlah UMKM menyumbang $90 \%$ pertumbuhan bagi ekonomi Indonesia. Pengembangan UMKM menjadi relevan dilakukan diIndonesia mengingat struktur usaha yang berkembang di Indonesia selama ini bertumpu pada keberadaan industri kecil dan menengah. Perhatian terhadap UMKM semakin besar manakala sektor ini mampu melewati krisis ekonomi yang terjadi di tahun 1997/1998. Krisis ekonomi yang ditandai dengan kebangkrutan perusahaan-perusahaan besar tidak membuat UMKM ikut gulung tikar. Keadaan ini membuktikan bahwa sektor UMKM sangat tangguh dan fleksibel dalam menghadapi kondisi perekonomian.

Meskipun memiliki peran yang sangat strategis, pengembangan UMKM juga bukan merupakan hal yang mudah, peranan pemilik UMKM sangat dibutuhkan untuk menghadapi tantangan perkembangan UMKM sekarangini. Dalam UMKM biasanya pengusaha merupakan pemilik sekaligus pengelola perusahaan, oleh karena itu pengusaha mempunyai tanggung jawab penuh terhadap usaha yang dijalankan sehingga semua keputusan yang bersangkutan dengan perusahaan sepenuhnya berada ditangan mereka (Kaukab et al, 2020) Sekarang ini semakin disadari bahwa harus ada upaya yang dilakukan untuk mengantisipasi mengenai kegagalan usaha. Tidak bisa dipungkiri bahwa di era globalisasi ini, apabila pelaku usaha tidak memiliki dalam kemampuan dalam mengelola usaha, usaha tersebut tidak bisa bersaing. Peningkatan daya saing suatu perusahaan memerlukan kemampuan untuk mengelola keuangan yang baik, salah satunya dengan memanfaatkan informasi akuntansi (Auliah dan Kaukab, 2019)

Informasi akuntansi merupakan bagian yang terpenting dari seluruh informasi yang diperlukan manajemen terutama yang berhubungan dengan data keuangan suatu perusahaan (Baridwan, 2000). Tujuan informasi akuntansi tersebut adalah memberikan petunjuk dalam memilih tindakan yang paling baik untuk mengalokasikan sumber daya yang langka pada aktivitas bisnis dan ekonomi (Ikhsan dan Ishak, 2005). Dalam berbagai aktivitas usaha, informasi akuntansi dipandang potensial karena mampu memberikan kontribusi terhadap berbagai tindakan yang bisa dijadikan pertimbangan dalam perencanaan, pengawasan, pengendalian dan pengambilan keputusan, oleh karena itu para pengusaha kecil dan menengah dituntut untuk memiliki kemampuan menganalisis dan menggunakan dataakuntansi.

Di Indonesia sebenarnya kewajiban menyelenggarakan pencatatan akuntansi yang baik yang ditujukan kepada pengusaha UMKM sudah tersirat dalam UU Tentang Usaha Kecil No. 9 Tahun 1995 dan UU Perpajakan No. 2 Tahun 2007 tentang Pengembangan Usaha Kecil Menengah dan Koperasi (Pinasti, 2007). Diharapkan akuntansi dapat dilaksanakan dalam berbagai organisasi karena semakin rumitnya beberapa variabel yang dihadapi termasuk dalam perusahaan kecil sekalipun (Jusup, 2003).

Pelaksanaan pembukuan akuntansi untuk menyediakan laporan keuangan yang informatif merupakan hal yang masih sulit dilakukan oleh para pelaku UMKM.Hal tersebut karena, lemahnya kemampuan yang dimiliki oleh pelaku usaha terutama mengenaipengetahuan tentang akuntansi untuk mengelola keuangan usahanya dalam menyediakan informasi akuntansi yang informatif. Menurut Marbun (1997) dalam Pinasti (2007), pada umumnya usaha kecil tidak atau belum memiliki dan mengelola catatan akuntansi secara ketat dan disiplin dengan pembukuan yang teratur, baik dalam bentuk harian, mingguan, bulanan, dan seterusnya. Hal ini disebabkan karena 
keterbatasan pengetahuan dalam pembukuan akuntansi, rumitnya proses akuntansi, dan anggapan bahwa laporan akuntansi bukan merupakan hal yang penting bagi UMKM (Rudianto dan Siregar, 2012).

Persepsi seseorang terhadap suatu hal pada dasarnya dipengaruhi oleh beberapa faktor. Faktor tersebut bisa berasal dari luar maupun dari dalam diri pelaku usaha. Faktorfaktor yang mempengaruhi persepsi yang berasal dari luar meliputi intensitas, ukuran, keberlawanan, pengulangan, gerakan, dan halhal baru berikut ketidakasingan. Selain faktor dari luar, faktor-faktor dari dalam diri seseorang yang mempengaruhi persepsi antara lain proses belajar, motivasi, dankepribadian (Kiryanto dkk. 2001). Seorang pelaku usaha semestinya memiliki pandangan bahwa usahanya sangat penting untuk diterapkan.Persepsi tersebut tentunya bisa muncul seiring berjalannya usaha, namun kebanyakan para pelaku usaha memiliki banyak pengalaman dalam mengelola usaha yang dijalankan atas pemahaman mereka tentang pentingnya pengelolaan keuangan usaha masih kurang.

Pengetahuan akuntansi merupakan pengetahuan mengenai cara mengelompokkan, menganalisis, mencatat hal-hal yang berhubungan dengan aktivitas keuangan perusahaan. Dalam penelitiannya, Kiryanto dkk. (2001), menjelaskan bahwa pengetahuan pemilik UMKM tentang informasi akuntansi sangat kurang sekali. Pengetahuan akuntansi perlu dimiliki oleh pengusaha dimana dapat digunakan untuk membantu pemilik yang juga sebagai pengelola usaha melakukan manajemen padausahanya.

Pengalaman usaha merupakan pembelajaran dari apa yang telah diperoleh pelaku usaha atas kegiatan usaha yang dijalankan. Pemilik usaha akan membutuhkan informasi yang lebih banyak untuk disiapkan dan digunakan dalam pengambilan keputusan yang dimiliki oleh seorang pelaku usaha dalam operasional perusahaan yang sudah dijalankan. Semakin lama perusahaan beroperasi informasi akuntansi semakin dibutuhkan, karena kompleksitas usaha juga semakin tinggi.dan mengindikasikan kebutuhan informasi akuntansi akan meningkat (Nicholls dan Holmes, 1988) dalam Fitriyah (2006).
Suatu pengalaman riil akan membentuk pandangan yang tepat atas informasi akuntansi denganadanya proses belajar dan pengalaman yang dimiliki dalam memahami informasi akuntansi.

Menurut Nawawi (2005), Motivasi adalah suatu kondisi yang mendorong atau menjadi sebab seseorang melakukan suatu perbuatan atau kegiatan, yang berlangsung secara sadar. Motivasi kerja seseorang tergantung pada kekuatan dari motivasi itu sendiri untuk dapat melakukan upaya nyata atas motivasi yang ada pada diri pelaku usaha yang nantinya dapat membuat mereka berperilaku pada saat menjalankan usahanya. Seorang pelaku usaha memerlukan motivasi kerja untuk membangun usahanya agar semakin berkembang. Keadaan tersebut juga menguatkan bahwamotivasi kerja yang tinggi bisa menjadi aspek penting yang mampu mempengaruhi persepsi seseorang dalam menerapkan penggunaan informasi akuntansi pada usahamereka.

Jenjang pendidikan adalah tahapan dasar yang ditetapkan berdasarkan tingkat perkembangan peserta didik, tujuan yang akan dicapai dan kemampuan yang dikembangkan (UU No. 20 Tahun 2003 Bab 1, Pasal 1, Ayat 8). Tingkat pendidikan berpengaruh terhadap perubahan sikap dan perilaku hidup sehat. Tingkat Pendidikan yang pernah ditempuh oleh pemilik/manajer UMKM memengaruhi pemahaman mengenai usaha yang sedang dijalankan dan pentingnya penggunaan informasi akuntansi bagi usaha mereka. Tingkat Pendidikan yang rendah akan membuat informasi akuntansi semakin jarang untuk digunakan karena kurangnya pemahaman.

Skala usaha merupakan ukuran yang dipakai untuk mencerminkan besar kecilnya perusahaan. (Suwito dan Herawaty, 2005). Klasifikasi ukuran perusahaan menurut UU No. 20 Tahun 2008 dibagi ke dalam 4 (empat) kategori, yaitu usaha mikro, usaha kecil, usaha menengah, dan usaha besar yang dibedakan menurut perputaran dan aset yang dimiliki perusahaan. Skala usaha merupakan salah satu indikasi perkembangan suatu perusahaan dimana perusahaan yang besar akan membawa dampak bagi karyawan yang terlibat didalamnya. 
Bertambahnya karyawan dari tahun ketahun menandakan perusahaan tumbuh dan berkembang dikarenakan perusahaan yang besar akan membutuhkan karyawan dengan jumlah yang besar pula. Jika skala usaha meningkat, maka proporsi perusahaan dalam menyediakan informasi akuntansi, dan informasi tambahan juga meningkat (Meliana \& Dewi, 2015). Penggunaan informasi akuntansi akan sangat membantu dalam mengelola kompleksitas suatu perusahaan.

Di era digital saat ini sebagian besar pelaku UMKM masih "buta" akuntansi.Akibatnya, wajar jika banyak di antara mereka tidak memiliki pembukuan pada bisnisnya yang berpotensi makin membesar. Saat ini jumlah usaha kecil di Indonesia sudah mencapai $93,4 \%$, dan usaha menengah berada di angka 5,1\%, sedangkan usaha besar hanya $1 \%$ (Kompas.com, 2018). Upaya pemerintah dalam rangka peningkatan SDM bagi UKM di Kabupaten Wonosobo khususnya dan Provinsi Jateng pada umumnya yaitu melalui Balai Pelatihan Koperasi, Usaha Kecil, dan Menengah Dinas Koperasi \& UKM Jateng. Melalui pelatihan ini diharapkan peserta bisa kritis untuk mencari informasi. Selain itu sebagai pelaku UKM, peserta pelatihan harus memperbanyak inovasi produk. Bank Jateng melalui program micro business simulation juga memberikan pelatihan kepada peserta.(Balatkop Jateng,2019).

Terkait permasalahan terhadap UMKM menurut Magelangekspres.com, (2020) menyatakan bahwa total jumlah pelaku UMKM di Kabupaten Wonosobo dikisaran 60 ribu pelaku. Namun, upaya untuk meningkatkan kelas masih cukup kesulitan karena terhalang oleh mindset pelaku, manajemen usaha yang buruk serta minimnya anggaran fasilitasi dari pemkab. "Kisaran jumlahnya sudah mencapai 60 ribu pelaku.Upaya untuk meningkatkan kapasitas terus dilakukan dengan pelatihan dan juga perluasan pasar," ungkap Kabid UMKM dan Koperasi Disdagkop UMKM Wonosobo, Nugrohadi kemarin.Menurutnya, pengembangan UMKM di Wonosobo tidak mudah untuk ditingkatkan atau naik kelas. Sebab, masih ada pola pikir dari pelaku usaha yang belum membuka diri untuk bertahan dan berinovasi agar produk tetap di terima pasar secara luas. "Pelaku usaha harus kreatif dan inovatif, meski produknya bagus. Jika tidak didukung oleh packing dan promosi akan tenggelam," ucapnya. Pada sisi manajemen usaha, sebagian pesar pelaku masih menggunakan hitungan kira-kira, belum didasarkan pada perhitungan yang cermat da realisitis. Sehingga, tidak berumur panjang, ramai diawal, namun akhirnya kolaps dan ambruk."Pelaku usaha yang gagal mengatur usahanya baik dari sisi keuangan dan sisi produksi maka bisa dipastikan tidak tahan lama, alias berumur pendek," bebernya.

Berbagai macam keterbatasan lain dihadapi oleh UMKM mulai dari latar belakang pendidikan yang tidak mengenal mengenai akuntansi atau tata buku, kurang disiplin dan rajinnya dalam pelaksanaan pembukuan akuntansi, hingga tidak adanya kecukupan dana untuk mempekerjakan akuntan atau membeli software akuntansi untuk mempermudah pelaksanaan pembukuan akuntansi. Selain itu dalam upaya berkembang atau tetap hidup, UMKM menghadapi berbagai kendala atau masalah antara lain disebabkan rendahnya pendidikan, kurangnya pemahaman tekhnologi informasi, ukuran usaha, dan kurangnya pendalaman karakteristik laporan keuangan merupakan faktor yang sulit dipisahkan dengan lingkungan pengusaha UMKM (Arizali, 2013).

Berbagai macam keterbatasan lain dihadapi oleh UMKM mulai dari latar belakang pendidikan yang tidak mengenal mengenai akuntansi atau tata buku, kurang disiplin dan rajinnya dalam pelaksanaan pembukuan akuntansi, hingga tidak adanya kecukupan dana untuk mempekerjakan akuntan atau membeli software akuntansi untuk mempermudah pelaksanaan pembukuan akuntansi. Selain itu dalam upaya berkembang atau tetap hidup, UMKM menghadapi berbagai kendala atau masalah antara lain disebabkan rendahnya pendidikan, kurangnya pemahaman tekhnologi informasi, dan ukuran usaha. Jenjang Pendidikan yang lebih tinggi akan lebih banyak memperoleh informasi dan mengimplementasikan dalam kehidupan sehari-hari. Sehingga dengan jenjang pendidikan yang tinggi akan lebih mudah memahami tentang penggunaan informasi akuntansiSedangkan skala usaha yaitu, 
kemampuan perusahaan dalam mengelola usahanya dengan melihat berapa jumlah karyawan yang dipekerjakan dan berapa besar pendapatanyang diperoleh peusahaan dalam satu periode akuntansi. Jumlah pendapatan atau penjualan yang dihasilkan perusahaan dapat menunjukan perputaran asset atau modal yang dimiliki oleh perusahaan sehingga semakin besar pula tingkat kompleksitas perusahaan dalam menggunakan informasiakuntansi.

\section{LANDASAN TEORI DAN PENGEMBANGAN HIPOTESIS}

Penggunaan informasi akuntansi merupakan pemanfaatan informasi- informasi akuntansi yang berasal dari catatan-catatan akuntansi dalam pengambilan keputusan bisnis atau Penggunaan Informasi akuntansi dapat menjadi dasar yang andal bagi pengambilan keputusan-keputusan dalam pengelolaan usaha kecil, antara lain keputusan pengembangan pasar, penetapan harga, dan lain-lain, dalam hubungan usaha kecil dengan pemerintah dan kreditur (bank), penyediaan informasi akuntansi juga diperlukan untuk pengembangan usaha. Beberapa faktor yang diperkirakan berpengaruh terhadap penggunaan informasi akuntansi pada pelaku UMKM dalam penelitian ini mencakup pengetahuan akuntansi, pengalaman usaha, mtivasi kerja, jenjang pendidikan, dan skala usaha.

Pengetahuan akuntansi adalah pengetahuan tentang akuntansi yang dimiliki oleh pengusaha kecil dan menengah. Menurut Jusuf (2003) akuntansi adalah proses pencatatan, penggolonggan, ringkasan, pelaporan, dan penganalisaan data keuangan suatu organisasi. Proses belajar mengenai akuntansi akan meningkatkan pengetahuan akuntansi pengusaha (manager), sehingga pemahaman pengusaha (manager)untuk menerapkan informasi akuntansi juga akan semakin meningkat. Widiyanti (2013) yang menemukan bahwa Pengetahuan Akuntansi berpengaruh positif terhadap Persepsi Pengusaha Kecil dan Menengah atas Informasi Akuntansi. Hasil penelitian yang dilakukan olehFitriyah (2006) juga menunjukkan bahwa Pengetahuan Akuntansi berpengaruh signifikan terhadap Penggunaan Informasi
Akuntansi dan menjelaskan bahwa Pengetahuan Akuntansi sangat diperlukan oleh pemilik perusahaan dalam menjalankan operasionalperusahaan. Hasil penelitian dari Dwi Lestanti (2015) membuktikan bahwa pengetahuan akuntansi berpengaruh positif terhadap penggunaan informasi akuntansi pada pelaku UMKM.Berdasarkan uraian sebelumnya dapat disimpulkan bahwa pengetahuan akuntansi berperan penting bagi pelaku UMKM atau pemilik perusahaan dalam menjalankan operasional perusahaan.Karena semakin meningkatnya pengetahuan akuntansi yang di miliki oleh para pelaku UMKM semakin meningkatnya juga dalam penggunaan informasi akuntansi.

$\mathrm{H}_{1}$ : Pengetahuan akuntansi berpengaruh positif terhadap penggunaan informasi akuntansi akuntansi pada pelakuUMKM

Pengalaman usaha adalah proses pembentukan pengetahuan atau keterampilan tentang metode suatu pekerjaan karena keterlibatan karyawan tersebut dalam pelaksanaan tugas pekerjaan Manulang (1984). Pengalaman kerja adalah ukuran tentang lama waktu atau masa kerja yang telah ditempuh seseorang dapat memahami tugas-tugas suatu pekerjaan dan telah melaksanakan dengan baik Ranupandojo (1984). Pengalaman kerja adalah pengetahuan atau keterampilan yang telah diketahui dan dikuasai seseorang yang akibat dari perbuatan atau pekerjaan yang telah dilakukan selama beberapa waktu tertentu Trijoko(1980).Pengalaman pengusaha yang diperoleh dari banyaknya pembelajaran tentang informasi yang dibutuhkan dan digunakan dalam pengambilan keputusan akan menentukan persepsi pengusaha tersebut atas informasi akuntansi keuangan. Seorang pengusaha akan membutuhkan informasi akuntansi yang lebih banyak untuk penyiapan dan penggunaan dalam pengambilan keputusan apabila tingkat kompleksitas usaha serta persaingan dalam dunia usaha semakin ketat. Pengalaman pengusaha dalam bidang usahanya atau lamanya perusahaan beroperasi berdasarkan pada bisnis yang sudah dijalankan akan mengindikasikan kebutuhan akan informasi akuntansi, semakin lama perusahaan beroperasi informasi akuntansi semakin dibutuhkan karena kompleksitas usaha juga semakin tinggi. Siti Fithoriah dan Ari 
Pranaditya (2019) menyatakan bahwa pengalaman usaha berpengaruh signifikan terhadap penggunaan informasi akuntansi. Hasil penelitian dari Dwi Lestanti (2015) membuktikan bahwa pengalaman usaha berpengaruh positif terhadap penggunaan informasi akuntansi pada pelaku UMKM.Berdasarkan uraian sebelumnya dapat disimpulkan bahwa pengalaman usaha merupakan proses pembentukan pengetahuan atau keterampilan yang telah dikuasai oleh pemilik usaha dalam menjalankan operasional perusahaan. Semakin meningkatnya pengalaman usaha yang sudah di lalui oleh pemilik usaha maka semakin meningkatnya juga dalam penggunaan informasi akuntansi.

$\mathrm{H}_{2}$ : Pengalaman usaha berpengaruh positif terhadap penggunaan informasi akuntansi akuntansi pada pelakuUMKM.

Pamela \& Oloko (2015) Motivasi adalah kunci dari organisasi yang sukses untuk menjaga kelangsungan pekerjaan dalam organisasi dengan cara dan bantuan yang kuat untuk bertahan hidup. Motivasi adalah memberikan bimbingan yang tepat atau arahan, sumber daya dan imbalan agar mereka terinspirasi dan tertarik untuk bekerja dengan cara yang anda inginkan.Chukwuma \& Obiefuna (2014) Motivasi adalah proses membangkitkan perilaku, mempertahankan kemajuan perilaku, dan menyalurkan perilaku tindakan yang spesifik. Dengan demikian, motif (kebutuhan, keinginan) mendorong karyawan untuk bertindak. Motivasi adalah suatu proses yang dimulai dengan kebutuhan dalam diri manusia yang menciptakan kekosongan dalam diri seseorang (Chukwuma \& Obiefuna, 2014). Hasil penelitian dari Dwi Lestanti (2015) membuktikan bahwa motivasi kerja berpengaruh positif terhadap penggunaan informasi akuntansi pada pelaku UMKM.Dapat dismpulkan bahwa motivasi adalah suatu proses dimana kebutuhan mendorong seseorang untuk melakukan serangkaian kegiatan yang mengarah ke tercapainya tujuan tertentu. Tujuan yang jika berhasil dicapai akan memuaskan atau memenuhi kebutuhan-kebutuhan tersebut.

$\mathrm{H}_{3}$ : Motivasi Kerja berpengaruh positif terhadap penggunaan informasi akuntansi akuntansi pada pelaku UMKM.
Jenjang pendidikan adalah tahapan dasar yang ditetapkan berdasarkan tingkat perkembangan peserta didik, tujuan yang akan dicapai dan kemampuan yang dikembangkan (UU No.20 Tahun 2003 Bab 1, Pasal 1, Ayat 8). Jenjang pendidikan formal terdiri atas pendidikan dasar, pendidikan menengah, dan pendidikan tinggi.Tingkat pendidikan formal yang rendah (tingkat pendidikan sekolah dasar sampai dengan sekolah menengah umum) pemilik atau manajer akan rendah dalam penggunaan informasi akuntansi dibandingkah tingkatan pendidikan formal yang tinggi (Perguruan tinggi) pemilik atau manajer. Ini disebabkan materi pengajaran akuntansi lebih tinggi diberikan diperguruan tinggi dibandingkan dengan pendidikan yang lebih rendah Handayani (2011).Murniati (2002) menemukan bahwa pengusaha dengan jenjang pendidikan formal yang rendah cenderung tidak memiliki persiapan dan penggunaan informasi akuntansi yang memadai dibandingkan pengusaha yang memiliki pendidikan formal lebih tinggi.Hal tersebut dikarenakan materi akuntansi didapatkan pada jenjang pendidikan yang lebih tinggi. Penelitian tersebut didukung oleh Solovida (2003), Pratiwi (2008), Wahyudi (2009), dan Muchdorroh (2012).Hasil penelitian dari Awanda Nirwana, Dendi Purnama (2019) membuktikan bahwa jenjang pendidikan berpengaruh positif terhadap penggunaan informasi akuntansi pada pelaku UMKM. Vivi Anggraini Dwi Wulandari (2016) menyatakan jenjang pendidikan berpengaruh signifikan terhadap penggunaan informasi akuntansi. Dapat disimpulkan bahwa pemilik usaha yang memiliki jejang pendidikan yang tinggi lebih memiliki persiapan dalam penggunaan informasi akuntansi yang lebih memadai dibandingkan pemilik usaha yang memliki jenjang pendidikanrendah.

$\mathrm{H}_{4}$ : Jenjang pendidikan berpengaruh positif terhadap penggunaan informasi akuntansi akuntansi pada pelaku UMKM

Kemampuan perusahaan dilihat dari total asset, jumlah karyawan, serta besarnya pendapatan selama satu periode akuntansi, hal itulah yang disebut skala usaha.Jika perusahaan sudah besar dan maju, maka perusahaan tersebut membutuhkan jumlah karyawan yang banyak untuk menjalankan 
aktifitas yang ada di perusahaan Yasa, Herawati, \& Sulindawati (2017).Pertambahan asset akan membuat perusahaan memperhatikan lebih detail terkait rincian asset yang dimilikinya, bukan hanya asset yang dimiliki tetapi juga penggunaan atas asset tersebut. Skala usaha yang semakin besar, semakin kompleks masalah yang ada di dalam perusahaan sehingga manajer membutuhkan informasi yang relevanuntuk membuat keputusan dalam menentukan langkah-langkah yang harus diambil dimasa yang akan datang.Hasil penelitian dari Naufal Irfa Nabawi (2018) membuktikan bahwa skala berpengaruh positif terhadap penggunaan informasi akuntansi pada pelaku UMKM. Yulia Astuti (2017) juga menyatakan bahwa skala usaha berpengaruh positif terhadap penggunaan informasi akuntansi.Dapat disimpulkan bahwa skala yang semakin besar jika dilihat dari ukuran perusahaan, hasil pendapatan dan banyaknya karyawan, akan semakin meningkat juga dalam penggunaan informasi akuntansi di dalam perusahaan.

$\mathrm{H}_{5}$ : Skala usaha berpengaruh positif terhadap penggunaan informasi akuntansi akuntansi pada pelaku UMKM.

\section{METODE}

Jenis penelitian ini adalah kuantitatif yaitu penelitian yang menggunakan angka dalam penyajian data dan analisis yang menggunakan uji statistik. Populasi dalam penelitian ini adalah pemilik UMKM dengan jumlah 65.000 menurut LKJIP tahun 2016 UMKM di Kabupaten Wonosobo. Teknik pengambilan sampel dilakukan dengan simple random sampling. Jumlah sampel minimal berdasarkan perhitungan rumus slovin adalah 99,8484 atau dibulatkan menjadi 100, namun dalam penelitian ini kuesioner disebar sebanyak 110 sampel. Model yang digunakan untuk menguji hipotesis dalam penelitian ini menggunakan analisis regresi linier berganda.

Variabel dependen dalam penelitian ini adalah penggunaan informasiakuntansi yang diukur dengan indikator penggunaan informasi operasional, penggunaan informasi akuntansi keuangan, penggunaan informasi akuntnasi pajak, penggunaan informasi akuntansi menejemen (Naufal Ira Nabawi, 2018). Variabel independen dalam penelitian ini adalah pengetahuan akuntansi, pengalaman usaha, motivasi kerja, pengalaman usaha dan skala usahadalam penggunaan informasi akuntansi. Indikator penggunaan informasi akuntansi yaitu penggunaan informasi operasional, penggunaan informasi akuntansi keuangan, penggunaan informasi akuntnasi pajak, penggunaan informasi akuntansi menejemen (Naufal Ira Nabawi, 2018).Indikator pengetahuan akuntansi yaitu pengetahuan deklaratif, pengetahuan prosedural (Naufal Ira Nabawi, 2018). Indikator pengalaman usaha yaitu :lama usaha, tingkat pengetahuan, penguasaan terhadap peralatan (Muhammad Dwi Januar, 2017). Indikator motivasi kerja yaitu motivasi untuk berprestasi, motivasi terhadap kekuasaan, motivasi untuk bersahabat kontribusi (Sohail, Safdar, Saleem, Ansar, dan Azeem, 2014). Indikator partisipasi dalam jenjang pendidikan yaitu proses pemilik/manajer untuk meningkatkan pengetahuan, kemampuan teknis,kemampuan organisasi (Naufal Ira Nabawi, 2018). Indikator partisipasi dalam skala usaha yaitu karyawan, pendapatan,danaset (Hendra Budiyanto, 2014). Semua variabel diukur dengan kuesioner dengan 5 poin skala likert.

\section{HASIL}

\section{Hasil}

Uji F merupakan uji Goodness of Fit yang digunakan untuk mengukur ketepatan fungsi regresi sampel dalam menaksir nilai aktual. Disimpulkan dari Tabel 1bahwa F hitung lebih besar dari $\mathrm{F}$ tabel yaitu20,960 $>270$ dengan tingkat signifikan di bawah 0,05 yaitu 0,000 . Nilai $F$ tabel di peroleh dari N-K$\mathrm{I}=95$ (dimana $\mathrm{N}=$ jumlah sampel, $\mathrm{K}=$ jumlah variabel independen, I= konstanta). Sehingga dapat disimpulkan bahwa variabel pengetahuan akuntansi, pengalaman usaha, motivasi kerja, jenjang pendidikan, dan skala usaha berpengaruh terhadap dalam penggunaan informasi akuntansi pada pelaku UMKM sudah sesuai atau Fit Tabel 1 Pengujian Goodness of Fit Model (Uji F)

\begin{tabular}{llllcc}
\hline Model & $\begin{array}{l}\text { Sum of } \\
\text { Squares }\end{array}$ & df & $\begin{array}{l}\text { Mean } \\
\text { Square }\end{array}$ & F & Sig \\
\end{tabular}




\begin{tabular}{lrrrrr}
\hline Regression & 384.874 & 5 & 76.975 & 20.960 & .000 \\
Residual & 337.871 & 92 & 3.673 & & \\
Total & 722.745 & 97 & & & \\
\hline
\end{tabular}

Sebelum dilakukan pengolahan data, data yang diperoleh melalui kuesioner perlu untuk diuji kebenaran dan kehandalanya.Pengujian dilakukan dengan pengujian validitas dan reliabilitas.Hasil uji validitas menunjukan bahwa variabel kualitas penggunaan informasi akuntansi pada pelaku UMKM memiliki kisaran korelasi $0,703^{* *}$ sampai $0,737 * *$ dengan tingkat signifikasi 0,000.Hal ini menunjukkan bahwa pertanyaanpertanyaan tentang penggunaan informasi akuntansi dapat dinyatakan valid.Variabel pengetahuan akuntansi memiliki kisarankorelasi $0,840 * *$ sampai $0,872 * *$ dengan tingkat signifikasi 0,000 .Hal ini menunjukkan bahwa pertanyaan-pertanyaan tentang pengetahuan akuntansi dapat dinyatakan valid. Pengalaman usaha memiliki kisaran korelasi $0,918 * *$ sampai $0,931 * *$ dengan tingkat signifikasi $0,000$. Hal ini menunjukkan bahwa pertanyaan-pertanyaan tentang pengalaman usaha dapat dinyatakan valid.Motivasi kerja memiliki kisaran korelasi $0,921 * *$ sampai $0,927 * *$ dengan tingkat signifikasi 0,000.Hal ini menunjukkan bahwa pertanyaan-pertanyaan tentang motivasi kerja dinyatakan valid.Jenjang pendidikan dalam penyusunan anggaran memiliki kisaran korelasi $0,845^{* *}$ sampai $0,812^{* *}$ dengan tingkat signifikasi 0,000 .Hal ini menunjukkan bahwa pertanyaan-pertanyaan tentang dalam pendidikan dapat dinyatakan valid. Skala usaha dalam penggunaan informasi akuntansi memiliki kisaran korelasi $0,850 * *$ sampai $0,8842 * *$ dengan tingkat signifikasi 0,000 . Hal ini menunjukkan bahwa pertanyaanpertanyaan tentang partisipasi dalam jenjang pendidikan dapat dinyatakanvalid. Hasil uji reliabilitas menggunakan Cronbach Alpha dengan hasil semua variabel dalam penelitian memiliki alpha lebih besar dari 0,6 maka hasil penelitian ini menunjukkan bahwa alat pengukuran dalam penelitian ini telah memenuhi syarat uji reabilitas karena reliabel dan dapat digunakan sebagai alat ukur. Sehingga seluruh pertanyaan yang berkaitan dengan sistem akuntansi manajemen, kepribadian kewirausahaan, desentralisasi dan partisipasi dalam penyusunananggran.

Uji asumsi klasik dilakukan sebelum menguji hipotesis.Hasil perhitungan normalitas dengan menggunakan uji One Sample Kolmogorov-smirnov Test memiliki probabilitas tingkat signifikan diatas tingkat $\alpha$ $=0,05$ yaitu 0,200 . Hal ini berarti dalam model regresi terdapat variabel residual yang terdistribusi secara normal. Hasil uji heterokedastisitas menunjukkan bahwa semua nilai tolerance yakni pada variabel pengetahuan akuntansi, pengalaman usaha, motivasi kerja, jenjang pendidikan, dan skala usaha dalam penggunaan informasi akuntansi pada pelaku UMKM diatas nilai 0,1. Selain itu pada VIF pada semua variabel yakni dengan pengetahuan akuntansi, pengalaman usaha, motivasi kerja, jenjang pendidikan, dan skala usaha dalam penggunaan informasi akuntansi pada pelaku UMKM menunjukkan nilai kurang dari 10.Sehingga dapat disimpulkan bahwa dalam model regresi ini tidak terjadi gejala multikolonieritas.

Pengujian hipotesis pada penelitian ini menggunakan regresi linier berganda untuk menguji denganpengetahuan akuntansi, pengalaman usaha, motivasi kerja, jenjang pendidikan, dan skala usaha berpengaruh terhadap dalam penggunaan informasi akuntansi pada pelakuUMKM.

Tabel 2 Hasil Uji Analisis Regresi Linier Berganda

\begin{tabular}{lrrrrrr}
\hline \multirow{2}{*}{ Model } & \multicolumn{2}{c}{$\begin{array}{l}\text { Unstandardized } \\
\text { Coefficients }\end{array}$} & \multicolumn{2}{c}{$\begin{array}{c}\text { Standardized } \\
\text { Coefficients }\end{array}$} & \multirow{2}{*}{ Sig. } \\
\cline { 2 - 4 } & \multicolumn{1}{c}{ B } & \multicolumn{1}{c}{ Std. Error } & Beta & & \\
\hline (Constant) & 3.799 & 1.255 & & 3.028 & .003 \\
Pengetahuan akuntansi & .558 & .147 & .333 & 3.790 & .000
\end{tabular}




\begin{tabular}{llllll} 
Pengalaman usaha & .130 & .065 & .168 & 1.994 & .049 \\
Motivasi kerja & .110 & .055 & .161 & 2.003 & .048 \\
Jenjang pendidikan & .241 & .109 & .200 & 2.201 & .030 \\
Skala usaha & .185 & .083 & .180 & 2.231 & .028 \\
\hline
\end{tabular}

Tabel 2 menunjukkan hasil pengujian regresi linier berganda secara serentak terhadap seluruh vaiabel independen dalam penelitian ini. Berdasarkan tabel tersebut dapat diperoleh persamaan regresi linier berganda sebagai beikut :

$\mathrm{Y}=3,799+0,558 \mathrm{X} 1+0,130 \mathrm{X} 2+0,110 \mathrm{X} 3$ $+0,241 \mathrm{X} 4+0,185 \mathrm{X} 5$

1. Nilai konstanta $(\alpha)$ sebesar 3,799 (positif), menunjukkan bahwa ketika variabel independen (pengetahuan akuntansi, pengalaman usaha, motivasi kerja, jenjang pendidikan, dan skala usaha berpengaruh terhadap dalam penggunaan informasi akuntansi pada pelaku UMKM)dalam keadaan konstanta $(\mathrm{x}=0,03)$, maka UMKM yang menjadi sampel dalam penelitian ini cenderung memiliki kualitas informasi akuntansi yangbaik.

2. Hasil pengujian regresi linier berganda menunjukkan bahwa variabel kualitas pengetahuan akuntansi memiliki koefisien regresi sebesar 0,558 dengan nilai signifikansi 0,000 . Nilai ini lebih kecil dari nilai signifikansi $5 \% \quad(0,05)$. Dengan demikian, maka hipotesis pertama yang menyatakan bahwa pengetahuan akuntansiberpengaruh positif terhadap penggunan informasi akuntansi diterima.

3. Hasil pengujian regresi linier berganda menunjukkan bahwa variabel pengalaman usaha memiliki koefisien regresi sebesar 0,130 dengan nilai signifikansi 0,049 . Nilai ini lebih kecil dari nilai signifikansi 5\%
$(0,05)$. Dengan demikian, maka hipotesis kedua yang menyatakan bahwa pengalaman usaha berpengaruh positif terhadap penggunaan informasi akuntnasiditerima.

4. Hasil pengujian regresi linier berganda menunjukkan bahwa variabel motivasi kerja memiliki koefisien regresi sebesar 0,110 dengan nilai signifikansi 0,048 . Nilai ini lebih kecil dari nilai signifikansi 5\% $(0,05)$. Dengan demikian, maka hipotesisketiga yang menyatakan bahwa pengalaman usaha berpengaruh positif terhadappenggunan informasi akuntansi diterima, artinya semakin semakin baik motivasi kerja, maka semakin baik penggunaan informasi akuntansi dengan asumsi variabel lainnya dianggapkonstan.

5. Nilai koefisien regresi dari variabel partisipasi dalam jenjang pendidikan sebesar 0,241 dengan nilai signifikan sebesar 0,030. Nilai ini lebih kecil dari nilai signifikansi $5 \%(0,05)$. Dengan demikian, maka hipotesis keempat yang menyatakan bahwa jenjang pendidikan berpengaruh positif terhadap penggunan informasi akuntansi akuntansiditerima.

6. Nilai koefisien regresi dari variabel partisipasi dalam skala usaha sebesar 0,185 dengan nilai signifikan sebesar 0,028 . Nilai ini lebih kecil dari nilai signifikansi $5 \%$ $(0,05)$. Dengan demikian, maka hipotesis keempat yang menyatakan bahwa skala berpengaruh positif terhadap penggunan informasi akuntansi akuntansiditerima.

Tabel 3Hasil Pengujian Koefisien Determinasi

\begin{tabular}{|c|c|c|c|c|}
\hline Model & $\mathrm{R}$ & R Square & $\begin{array}{l}\text { Adjusted R } \\
\text { Square }\end{array}$ & $\begin{array}{l}\text { Std. Error of } \\
\text { the Estimate }\end{array}$ \\
\hline 1 & $\begin{array}{l}.000 \\
\mathrm{a}\end{array}$ & .000 & .054 & 1.91638 \\
\hline
\end{tabular}


Koefisien determinasi dinotasikan dengan adjusted $R$ square. Koefisien determinasi menunjukkan proporsi variabel terikat yang dapat dijelaskan oleh variabel bebas (Ghozali, 2011). Pada Tabel 3 menunjukkan bahwa koefesien determinasi yang menunjukkan Adjusted $R$ square sebesar 0,54 atau $5,4 \%$ yaitu presentase pengaruh pengetahuan akuntansi, pengalaman usaha, motivasi kerja, jenjang pendidikan dan skala usaha pada pemilik usaha UMKM di Kabupaten Wonosobosebesar 5,4\%. Sedangkan sisanya sebesar $94,6 \%$ dipengaruhi oleh variabel lain diluar dari penelitian ini.

\section{Pembahasan}

Dari Tabel 3 menunjukkan bahwa pengetahuan akuntansi berpengaruh positif penggunaan informasi akuntansi. Hasil penelitian ini sejalan dengan penelitianHasil penelitian dari Dwi Lestanti (2015) membuktikan bahwa pengalaman usaha berpengaruh positif terhadap penggunaan informasi akuntansi pada pelaku UMKM. UMKM di Kabupaten Wonosobo sudah memiliki pengetahuan akuntansi yang baik.Penelitian ini membuktikan bahwa dengan adanya informasi akuntansi yang baik, maka UMKM tersebut bisa lebih mudah untuk mengambil keputusan yang tepat sehingga UMKM tersebut bisa lebih berkembang. Selain itu juga proses belajar mengenai pengetahuan akuntansi akan meningkatkan pengetahuan akuntansi bagi pelaku UMKM. Dengan meningkatnya pengetahuan akuntansi para pelaku UMKM maka pemahaman pelaku UMKM untuk menerapkan penggunaan informasi akuntansi dalam usahanya juga akan semakin meningkat. Dapat dilihat dari jawaban 100 responden atau $83 \%$ sebagian responden menjawab setuju, yang artinya bahwa responden dalam penelitian ini sudah memiliki pengetahuan informasi akuntansi yang akurat dan baik. UMKM di Kabupaten Wonosobo yang sudah menerapkan pengetahuan informasi akuntansi yang baik yaitu Ayam Goreng Prapatan dan House Of Elena. UMKM House Of Elena dan Ayam Goreng termasuk salah satu UMKM yang sudah menggunakan pembukuan seperti mencatat pemasukan, pengeluaran dan memiliki buku khusus arus kas. Jika seorang pengusaha memiliki pengetahuan tentang akuntansi yang baik maka pengusaha ini akan dapat menggunakan dan memahami informasi-informasi akuntansi yang digunakan dalam pembuatan keputusan investasi.

Pengalaman usaha berpengaruh positif penggunaan informasi akuntansi. Artinya pengalaman usaha merupakan pembelajaran dari apa yang telah diperoleh pelaku usaha atas kegiatan usaha yang dijalankan. Penelitian ini sejalan dengan Hasil penelitian dari Dwi Lestanti (2015) membuktikan bahwa pengalaman usaha berpengaruh positif terhadap penggunaan informasi akuntansi pada pelaku UMKM.Dengan demikian pengalaman yang dimiliki oleh karyawan akan sangat membantu dalam proses penyajian informasi akuntansi yang berkualitas dan akan semakin efektif penggunaan sistem informasi akuntansi yang ada. Pengalaman kerja seseorang sangat mempengaruhi karakter seseorang dalam bekerja karena semakin lama seseorang bekerja sesuai dengan bidangnya tersebut, maka akan semakin baik juga kinerja seseorang dalam bekerja. Pengalaman berusaha memperoleh banyak pembelajaran tentang penggunaan informasi akuntansi yang dibutuhkan dan disiapkan serta digunakan dalam pengambilan keputusan. Manajemen perusahaan akan membutuhkan penggunaan informasi akuntansi yang lebih banyak akan disiapkan dan digunakan dalam pengambilan keputusan apabila tingkat kompleksitas usaha serta persaingan semakin ketat.Dapat dilihat dari jawaban 100 responden atau 85\% sebagian responden menjawab setuju, yang artinya bahwa responden dalam penelitian ini sudah memiliki pengalaman usaha yang membuat si pemilik memiliki inovasi dan ke hati-hatian dalam usahanya. UMKM di Kabupaten Wonosobo yang sudah menerapkan pengalaman usaha akuntansi yang baik yaitu Ayam Goreng Prapatan dan House Of Elena. Pengalaman usaha yang sudah dilalui Ayam Goreng Prapatan dan House Of Elena sudah sangat banyak, misalnya saja yang dilalui oleh House Of 
Elena yang dulunya mempunyai store yang masih gabung dengan rumah dan berada di gang yang sempit namu sekarang sudah pindah di lokasi dan tempatnya lebih strategis serta sudah menjadi store yang lebih besar.

Motivasi kerja berpengaruh positif penggunaan informasi akuntansi. Artinya bahwa motivasikunci dari usaha yang sukses untuk menjaga kelangsungan pekerjaan dalam usaha dengan cara dan bantuan yang kuat untuk bertahan hidup. Hasil penelitian ini sejalan dengan penelitian Hasil penelitian dari Dwi Lestanti (2015) membuktikan bahwa motivasi kerja berpengaruh positif terhadap penggunaan informasi akuntansi pada pelaku UMKM. Dengan demikian dapat diketahui bahwa semakin baik motivasi kerja maka akan berpengaruh juga terhadap optimalnya penggunaan informasi akuntansi. Sebaliknya semakin buruk atau lemahnya motivasi kerja maka akan mempengaruhi rendahnya kinerja para pelaku usaha. Hal ini karena motivasi kerja mampu meningkatkan kinerja akibat adanya semnagt dalam menjalankanusahanya.Dapat dilihat dari jawaban 100 responden atau 84\% sebagian responden menjawab setuju, yang artinya bahwa responden dalam penelitian ini sudah memiliki motivasi kerja yang mampu memberi semangat serta ketepatan dalam mengambil sebuah keputusan dan memiliki rasa tanggung jawab. UMKM di Kabupaten Wonosobo yang sudah menerapkan motivasi yang baik yaitu Ayam Goreng Prapatan. Motivasi yang biasanya di lakukan oleh pemilik usaha Ayam Goreng Prapatan yaitu berbicara dengan pelanggan.Dengan membuka komunikasi dengan pelanggan, para pelaku umkm bisa menyiapkan pengalaman yang lebih baik bagi calon pelanggan itu termasuk salah satu motivasi bagi dirisendiri.

Tabel 3 membuktikan bahwa jenjang pendidikan terhadap penggunaan informasi akuntansi berpengaruh positif terhadap penggunaan informasi akuntansi. Artinya Hal ini berarti semakin tinggi pendidikan yang ditempuh oleh pemilik akan menyebabkan peningkatan penggunaan informasi akuntansi pada usaha kecil dan menengah. Hasil penelitian ini sejalan dengan penelitian Hasil penelitian dari Awanda Nirwana, Dendi
Purnama (2019) membuktikan bahwa jenjang pendidikan berpengaruh positif terhadap penggunaan informasi akuntansi pada pelaku UMKM.Dengan demikian dapat di ketahui bahwa adanya jenjang pendidikan dalam menjalankan usaha lebih mempengaruhi pemilik usaha dalam menggunakan informasi akuntansi.Pendidikan formal yang ditempuh oleh manajer/pemilik perusahaan sangat berpengaruh terhadap keahlian dan kemampuan yang dimiliki manajer/pemilik usaha dalam mengelola usahanya. Tingkat pendidikan formal yang rendah pemilik/manajer maka akan rendah pula penyiapan dan penggunaan informasi akuntansinya dalam usahanya dibandingkan dengan pemilik/manajer yang memiliki tingkat pendidikan formal lebih tinggi. Pemilik atau manajer perusahaan yang memiliki tambahan pendidikan, maka akan berpengaruh terhadap penyiapan dan penggunaan informasi akuntansi, seperti semakin tingginya tingkat pendidikan seseorang dan pelatihan-pelatihan yang diikuti guna menunjang pengetahuan pemilik/manajer khususnya yang berkaitan dengan akuntansi. Faktor lain yang dapat mempengaruhi penggunaan informasi akuntansi manfaat pendidikan manajer/pemilik dengan adanya perbedaan tingkat pendidikan formal yang ditempuh. Pendidikan formal yang dimiliki oleh pemilik atau manajer dapat menambah keyakinan manajer dalam bertindak dalam menggunakan informasi akuntansi untuk pengambilan keputusan. Dapat dilihat dari jawaban 100 responden atau $85 \%$ sebagian responden menjawab setuju, yang artinya bahwa responden dalam penelitian ini sudah memiliki pendidikan yang lebih tinggi, maka dalam mengelola usaha dan menyusun laporan keuangan yang di hasilkan akan baik. UMKM di Kabupaten Wonosobo yang sudah menerapkan jenjang pendidikan yang baik yaitu Ganesha Operation.

Skala usaha terhadap penggunaan informasi akuntansi berpengaruh positif terhadap penggunaan informasi akuntansi. Artinyaskala usaha merupakan salah satu indikasi perkembangan suatu perusahaan, apabila usaha yang dijalankan semakin besar 
maka UMKM sendiri akan membutuhkan data yang semakin kompleks sebagai konsekuensi atas besarnya usaha. Hasil penelitian dari Naufal Irfa Nabawi (2018) membuktikan bahwa skala berpengaruh positif terhadap penggunaan informasi akuntansi pada pelaku UMKM. Dengan demikian dapat di ketahui bahwa adanya skala usaha yang lebih besar lebih membutuhkan penggunaan informasi akuntansi yang lebih lengkap.Jumlah karyawan pada suatu usaha dapat menunjukkan seberapa efektif perusahaan memperoleh pendapatan. Dengan jumlah karyawan yang proporsional dalam lingkup usaha UKM tersebut, maka akan mendorong efisiensi biaya sehingga pencapaian hasil usaha akan lebih maksimal. Penggunaan informasi akuntansi akan dipengaruhi oleh jumlah karyawan karena menunjukkan bagaimana sebuah informasi akuntansi yang ada, digunakan dalam keputusan dengan mempertimbangkan jumlah karyawan yang ada dalam perusahaan terseut, dalam hal ini UMKM. Selain jumlah karyawan, skala usaha juga ditentukan dengan seberapa besar jumlah pendapatan atau penjualan yang dihasilkan perusahaan. Sebab jumlah pendapatan dapat menunjukkan perputaran asset atau modal yang dimiliki oleh perusahaan. Sehingga semakin besar pendapatan atau penjualan yang diperoleh perusahaan semakin besar pula tingkat kompleksitas perusahaan dalam menggunakan informasi akuntansi. Dapat dilihat dari jawaban 100 responden atau 80\% sebagian responden menjawab setuju, yang artinya bahwa responden dalam penelitian ini sudah memiliki skala usaha yang lebih besar. UMKM di Kabupaten Wonosobo yang sudah memiliki perkembangan dalam usahanya yaitu House Of Elena.

\section{KESIMPULAN}

Berdasarkan hasil penelitian tentang analisis faktor yang mempengaruhi penggunaan informasi akuntansi pada UMKM di Wonosobo, maka dapat disimpulkan dengan adanya pengetahuan akuntansi yang berkualitas maka dalam penggunaan sistem akuntansi manajemen memegang peranan penting dalam suatu organisasi terutama dalam perencanaan, pengawasan serta pengendalian. Selain itu akan sangat memudahkan para manajer dalam menyediakan informasi untuk mendukung tindakan-tindakan manajemen secara tepat dapat membantu meningkatkan kinerja manajerial yang baik. Pengalaman usaha pengusaha yang diperoleh dari banyaknya pembelajaran tentang informasi yang dibutuhkan dan digunakan dalam pengambilan keputusan akan menentukan persepsi pengusaha tersebut atas informasi akuntansi keuangan. Seorang pengusaha akan membutuhkan informasi akuntansi yang lebih banyak untuk penyiapan dan penggunaan dalam pengambilan keputusan apabila tingkat kompleksitas usaha serta persaingan dalam dunia usaha semakinketat. Motivasi kerja positif terhadap penggunaan informasi akuntansi pada pelaku UMKM artinya suatu proses dimana kebutuhan kebutuhan mendorong seseorang untuk melakukan serangkaian kegiatan yang mengarah ke tercapainya tujuan tertentu. Tujuan yang jika berhasil dicapai akan memuaskan atau memenuhi kebutuhan-kebutuhantersebut. Pemilik usaha yang memiliki jejang pendidikan yang tinggi lebih memiliki persiapan dan penggunaan informasi akuntansi yang lebih memadai dibandingkan pemilik usaha yang memliki jenjang pendidikan rendah. Pertambahan asset akan membuat perusahaan memperhatikan lebih detail terkait rincian asset yang dimilikinya, bukan hanya asset yang dimiliki tetapi juga penggunaan atas asset tersebut. Skala usaha yang semakin besar, semakin kompleks masalah yang ada di dalam perusahaan sehingga manajer membutuhkan informasi yang relevan untukmembuat keputusan dalam menentukan langkah-langkah yang harus diambil dimasa yang akan datang.

Hasil penelitian ini diharapkan dapat memberikan manfaat bagi seluruh pelaku UMKM di kabupaten Wonosobo sebagai bahan pertimbangan dalam penentuan penggunaan informasi akuntansi pada pelaku UMKM agar tercapai kualitas penggunaan informasi akuntansi yang baik. Hal ini dapat dilakukan dengan meningkatkan pengetahuan akuntansi, pengalaman usaha, motivasi kerja, 
jenjang pendidikan dan skala usaha dalam penggunaan informasi akuntansi yang baik. Dalam penelitian ini tidak terlepas dari beberapa keterbatasan, diantaranya adalah hasil penelitian menunjukan bahwa sistem akuntansi manajemen, kepribadian kewirausahaan, desentralisasi, partisipasi dalam penyusunan anggaran terhadap kinerja manajerial sebesar 5,4\%. Artinya, masih terdapat variabel bebas lainya yang bisa mempengaruhi penggunaan informasi akuntansi pada pelaku UMKM yang tidak di teliti dalam penelitian ini. Dengan adanya keterbatasan pada penelitian ini disarankan pada penelitian selanjutnya untuk mengadakan penelitian dengan tema yang serupa, agar dapat mengembangkan hasil penelitian ini dengan mengangkat penggunaan informasi akuntansi pada pelaku UMKM atau variabel baru yang berpengaruh terhadap kinerja manajerial, selain yang digunakan oleh peneliti sebelumnya. Untuk penelitian-penelitian berikutnya diharapkan dapat menambah variabel bebas seperti lama usaha, masa pemimpin perusahaan, pelatihan usaha bagi manajer atau pemilik dan umur perusahaan yang belum digunakan dalam penelitian ini yang dapat mempengaruhi penggunaan informasi akuntansi pada pelaku UMKM.

\section{Daftar Pustaka}

Awanda Nirwana, Dendi Purnama, 2019. Pengaruh Jenjang Pendidikan, Skala Usaha Dan Lama Usaha Terhadap Penggunaan Informasi Akuntansi Pada Umkm Di Kecamatan Ciawigebang.

Arizali, 2013. Faktor-Faktor Yang Mempengaruhi Penggunaan Informasi Akuntansi Pada Usaha Mikro Kecil Dan Menengah (Studi Kasus Pada Usaha Mikro Kecil Dan Menengah Di Kabupaten Subang)

Auliah, M. R., \& Kaukab, M. E. (2019). Pengaruh tingkat pendidikan, pemahaman akuntansi, dan pelatihan penyusunan laporan keuangan terhadap pelaporan keuangan umkm berdasarkan sak etap (studi kasus pada UMKM di Kabupaten Wonosobo). Journal of Economic, Business and Engineering (JEBE), 1(1), 131-139.

Budiyanto, H, 2014. Analisis Faktor-faktor yang Mempengaruhi Penggunaan Informasi Akuntansi pada Perusahaan Tenun Troso Jepara. Skripsi Tertutup, Universitas Islam Nahdatul Ulama'.

Chukwuma \& Obiefuna, 2014.Pengaruh Kompetensi Dan Motivasi Terhadap Kinerja Karyawan Pada Badan Keuangan Daerah Kabupaten Musi Rawas Utara

Dwi Lestanti, 2015. Pengaruh Pengetahuan Akuntansi, Pengalaman Usaha, dan Motivasi Kerja terhadap Persepsi Penggunaan Informasi Akuntasi pada Pelaku UMKM diBoyolali.

Ghozali, I, 2013.Aplikasi Analisis Multivariate dengan Program IBM SPSS 21 Update PLS Regresi (7th ed.). Semarang: Badan Penerbit Universitas Diponegoro.

Hadiyah Fitriyah, 2006. "Analisis FaktorFaktor yang Mempengaruhi Penggunaan Informasi AkuntansiPada Usaha Menengah Kabupaten Sidoharjo.'Tesis. Surabaya: Fakultas EkonomiUNAIR.

Hemi Nur Rohmah, 2019. Pengaruh Modal, Sikap Kewirausahaan, Dan Lama Usaha Terhadap Pendapatan Pedagang Di Pasar Boja Kabupaten Kendal.

Hadari Nawawi, 2005. Manajemen Sumber Daya Manusia Untuk Bisnis yang Kompetitif. Yogyakarta: UGM Press.

Handayani, 2011. Faktor-faktor yang mempengaruhi struktur modal pada perusahaan publik sektor manufaktur.

Ikhsan dan Ishak, 2005.Pengaruh komitmen profesional pada kepuasan kerja 
auditor dengan motivasi sebagai variabel moderasi

Kaukab, M. E., Adawiyah, W. R., Setyanto, R. P., \& Suroso, A. (2020). Accelerating small firms' production process improvement through international market knowledge and valuable, rare, inimitable, and organized resources and capabilities. Business: Theory and Practice, 21(1), 322-328.

Kaukab, M. E. (2020). Indonesian Economic Outlook 2020: Peluang Dari Keterbukaan. Jurnal Penelitian dan Pengabdian Kepada Masyarakat UNSIQ, 7(1), 38-47.

Kiryanto, dkk. 2001. "Pengaruh Persepsi Manajer atas Informasi Akuntansi Keuanganterhadap Keberhasilan Perusahaan kecil." Jurnal Riset Akuntansi Indonesia Vol. 4/No. 2/2001, Yogyakarta: Fakultas Ekonomi dan Bisnis Universitas Gadjah Mada.

Murniati, 2002.Analisis faktor-faktor yang mempengaruhi penggunaan informasi akuntansi pada usaha kecil dan menengah (UKM) di Yogyakarta.

Naufal Irfa Nabawi, 2018. Analisis FaktorFaktor Yang Mempengaruhi Penggunaan Informasi Akuntansi Pada Usaha Mikro Kecil Dan Mengengah Di Kota Yogyakarta

Pinasti, Margani, 2007. "Pengaruh Penyelenggaraan dan Penggunaan Informasi Akuntansi terhadap Persepsi Pengusaha kecil atas Informasi Akuntansi: Suatu Riset Eksperimen." Jurnal Riset Akuntansi Indonesia Vol.10/No.3/2007. Makassar: Fakultas Ekonomi UniversitasHasanuddin.

Rudianto dan Siregar, 2012.Peningkatan Daya Saing Melalui Penyusunan Laporan Keuangan Bagi Pelaku Usaha Kecil Dan Menengah Kota Semarang
Siti Fithoriah, Ari Pranaditya, 2019. Pengaruh Tingkat Pendidikan, Pengetahuan Akuntansi, Pengalaman Usaha Dan Skala Usaha Terhadap Penggunaan Informasi Akuntansi Pada Usaha Kecil Menengah(Studi Kasus Pada Pelaku Ukm Di Jalan Karangjati Dan Jalan Pringapus Kabupaten Semarang).

Suwito dan Herawaty, 2005.Analisis Faktor Yang Mempengaruhi ManajamenLaba Studi Pada Perusahaan Yang Terdaftar di BEI)

Vivi Anggraini Dwi Wulandari, 2016. Pengaruh Jenjang Pendidikan, Lama Usaha, Skala Usaha, Dan Pengetahuan Akuntansi Terhadap Penggunaan Informasi Akuntansi Pada Umkm Mebel. Di Kabupaten Sragen.

Widiyanti, 2013.Analisis faktor faktor yang mempengaruhi persepsi pengusaha kecil dan menengah atas penggunaan informasi akuntansi keuangan

Yasa, Herawati, \& Sulindawati, 2017.Pengaruh Skala Usaha, Umur Perusahaan, Pengetahuan dan Akuntansi Terhadap Penggunaan Informasi Akuntansi pada Usaha Kecil Menengah.

Yuli Astiani, 2017. Pengaruh Persepsi Pelaku Usaha Mikro Kecil Dan Menengah Tentang Akuntansi, Pengetahuan Akuntansi, Dan Skala Usaha Terhadap Penggunaan Informasi Akuntansi . 